УДК: 159.9.072.432

https://doi.org/10.52058/2786-4952 -2021-5(5)-735-746

Вітомський Юрій Леонідович кандидат психологічних наук, член Національної психологічної асоціації, доцент кафедри кримінального права, процесу і криміналістики, Київський інститут інтелектуальної власності та права Національного університету «Одеська юридична академія», Харківське Шосе., 210, м. Київ, 02000, тел.: (0680) 884-88-44, u.vitomskyi@gmail.com, https://orcid.org/0000-0003-3094-5104

Бондаренко Степан Юрійович старший методист кафедри кримінального права, процесу i криміналістики, студент III курсу, Київський інститут інтелектуальної власності та права Національного університету «Одеська юридична академія», сертифікований партнер проєкту «Всеосвіта», Харківське Шосе., 210, м. Київ, 02000, тел.: (095) 551-26-12, bondarenko.stephan@ukr.net, https://orcid.org/0000-0001-8328-5117

Гученко Катерина Володимирівна студентка II курсу магістратури Київського інституту інтелектуальної власності та права Національного університету «Одеська юридична академія», Харківське Шосе., 210, м. Київ, e-mail: 0505685756@ukr.net

Абрамян Володимир Цолакович доцент, кафедри кримінального права, процесу і криміналістики, Київський інститут інтелектуальної власності та права Національного університету «Одеська юридична академія», Харківське Шосе., 210, м. Київ, тел.: (050)546-534, e-mail: vladabram@ukr.net

\title{
СУЧАСНІ МЕТОДИ ПРОФОРІЕНТАЦІЙНОЇ РОБОТИ ЯК УМОВА ФОРМУВАННЯ В УЧНІВ НУШ ЗДІБНОСТЕЙ ПЛАНУВАТИ ТА РЕАЛІЗОВУВАТИ ПЕРСОНАЛЬНИЙ ОСВІТНЬО-ПРОФЕСІЙНИЙ МАРШРУТ
}

Анотація. Стаття спрямована на аналіз та вдосконалення існуючих практик профорієнтації. Сьогодні змінюється дитина, світ професій, суспільство, зазнають змін професійно важливі якості, що ведуть за собою необхідність обгрунтування, наповнення новим змістом технологій професійного самовизначення. Мета статті - аналіз сучасних методів профорієнтаційної роботи в підлітковому та юнацькому віці, оцінка ефективності програм підготовки учнів до усвідомленого вибору професії в умовах життя, що постійно ускладнюються i розширюються. Автори наголошують на важливості формування готовності до усвідомленої та самостійної побудови персонального освітньо-професійного маршруту, 
активного включення учнів, їхніх батьків у процес самовизначення. Розглядаються основні методи профорієнтації: інформаційні, що активізують, розвивають, діагностико-консультаційні.

Цільова категорія дослідження - учні 7-9-х класів. Методи дослідження: теоретичні (аналіз психолого-педагогічної літератури), емпіричні (анкетування, тестування, що формує експеримент). Актуальною є розробка пропозицій щодо вдосконалення системи сучасної профорієнтації. Внаслідок переосмислення нових підходів до профорієнтації автори акцентують увагу на підготовці фахівців, які здійснюють психолого-педагогічну підтримку учнів у процесі формування та реалізації освітньо-професійного маршруту. Результати дослідження можуть бути покладені в основу проектування нових засобів та змісту професійного самовизначення.

Дослідження відповідає на важливий виклик сучасності - створення системи професійного самовизначення учнів та професійного зростання спеціалістів. Матеріали статті можуть бути використані студентамибакалаврами психолого-педагогічних напрямів підготовки, дослідниками та практиками, які займаються питаннями профорієнтаційної роботи, організації психологічної допомоги учням.

Ключові слова: професійне самовизначення, профорієнтація, освітньопрофесійний маршрут, методи профорієнтації, програма профорієнтації, НУШ.

Vitomsky Yuriy Leonidovych Candidate of Psychological Sciences, Member of the National Psychological Association, Associate Professor of Criminal Law, Procedure and Criminology, Kyiv Institute of Intellectual Property and Law of the National University "Odessa Law Academy", Kharkivske Shosse, 210, Kyiv, 02000, tel.: (068) 884-88-44, e-mail: u.vitomskyi@gmail.com, https://orcid.org/0000-00033094-5104

Bondarenko Stepan Yuriyovych Senior Methodist of the Department of Criminal Law, Procedure and Criminology, 3rd year student, Kyiv Institute of Intellectual Property and Law of the National University "Odessa Law Academy", certified partner of the project "Vseosvita", Kharkivske Shosse., 210, Kyiv, 02000, tel. .: (0950 551-26-12, e-mail: bondarenko.stephan@ukr.net, https://orcid.org/00000001-8328-5117

Guchenko Kateryna Volodymyrivna 2nd year master's student of the Kyiv Institute of Intellectual Property and Law of the National University "Odessa Law Academy", 02000, Kharkivske Shosse., 210, Kyiv, 0505685756@ukr.net

Abramyan Volodymyr Tsolakovych Associate Professor, Department of Criminal Law, Procedure and Criminology, Kyiv Institute of Intellectual Property and Law of the National University "Odessa Law Academy", Kharkivske Shosse, 210, Kyiv, 02000, tel .: (050) 546-534, e-mail: vladabram@ukr.net. 


\title{
MODERN METHODS OF VOCATIONAL GUIDANCE WORK AS A CONDITION FOR THE FORMATION OF ABILITIES OF NUS ABILITIES TO PLAN AND IMPLEMENT PERSONAL EDUCATIONAL EDUCATION
}

\begin{abstract}
The article is aimed at analyzing and improving existing career guidance practices. Today, the child, the world of professions, society are changing, professionally important qualities are changing, which lead to the need to substantiate, fill with new content technologies of professional self-determination. The purpose of the article is to analyze modern methods of career guidance work in adolescence and adolescence, to assess the effectiveness of programs to prepare students for a conscious choice of profession in a life environment that is constantly becoming more complicated and expanding. The authors emphasize the importance of forming readiness for conscious and independent construction of a personal educational and professional route, active involvement of students and their parents in the process of self-determination. The main methods of career guidance are considered: informational, activating, developing, diagnostic and consulting.

The target category of the research is students of 7-9 grades. Research methods: theoretical (analysis of psychological and pedagogical literature), empirical (questionnaires, testing, forming an experiment). It is important to develop proposals for improving the system of modern career guidance. As a result of rethinking new approaches to career guidance, the authors focus on training professionals who provide psychological and pedagogical support to students in the process of forming and implementing an educational and professional route. The results of the study can be used as a basis for designing new tools and content of professional selfdetermination.

The study responds to an important challenge of today - the creation of a system of professional self-determination of students and professional growth of professionals. The materials of the article can be used by bachelor students of psychological and pedagogical areas of training, researchers and practitioners who deal with issues of career guidance, organization of psychological assistance to students.
\end{abstract}

Keywords: professional self-determination, vocational guidance, educationalprofessional route, methods of vocational guidance, vocational guidance program, NUS.

Постановка проблеми. Профорієнтація учнів - пріоритетне державне завдання. Зараз учні включені в різноманітні профорієнтаційні формати: від профорієнтаційних тестів, які проходять більшість учнів, до екскурсій на підприємства, гуртків, профорієнтаційних програм, включення у профорієнтаційний напрямок добровольчої діяльності. Сміливо можемо визначити важливі завдання у профорієнтаційному напрямку, звертаючи увагу на вибудовування системи сучасної профорієнтації, на ранню профорієнтацію, місію педагога у визначенні нахилів учня та допомоги йому розвинутися у 
тому напрямку, де він демонструє здібності.

Професійна проба забезпечує занурення учнів у спеціально змодельоване професійне середовище, яке передбачає виконання завдань, пов'язаних із певною професією тощо.

В учнів викликають інтерес професійні проби з різними професійними компетенціями: підприємництво, промисловий дизайн, веб-дизайн, інформаційна безпека, інтернет речей, електроніка, ландшафтний дизайн, ветеринарія, викладання у молодших класах, робототехніка, кібербезпека, медицина, психологія, юриспруденція та ін. Практичною значимістю участі у профорієнтаційних заходах є отримання рекомендацій щодо вибору подальшої професійної траєкторії.

Для студентів реалізуються проекти, в рамках яких студент може подати результати дослідження, розроблені програми та проекти та отримати запрошення на стажування 3 подальшим працевлаштуванням. Майбутній спеціаліст має можливість апробувати свої інновації на базі конкретної установи, працювати під керівництвом досвідченого наставника. Таким чином, вибудовування індивідуальної освітньої траєкторії має здійснюватися спільно 3 педагогом-навігатором 3 використанням можливостей освітнього середовища (загальна освіта, профорієнтаційні заходи тощо).

Актуальність дослідження, по-перше, пов'язана 3 дефіцитом сучасних технологій профорієнтації, діагностичного інструментарію.

По-друге, дуже швидко змінюється світ професій. В даний час створено атлас актуальних професій, в якому постійно оновлюєтся список затребуваних професій, професій, в яких роботи не зможуть повністю замінити людину, і т. д. При організації профорієнтаційних заходів педагогам та психологам необхідно орієнтуватися на сучасну інформацію, обговорювати професії, які $\epsilon$ актуальними в даний час, і які будуть затребувані через певну кількість часу тощо.

По-третє, змінюється i той, хто навчається, i, відповідно, повинні змінюватися і використовувані профорієнтаційні технології. Необхідно враховувати, що в сучасних дітей має місце залежність від цифрових технологій, $є$ труднощі у встановленні прямого контакту з людьми тощо.

Аналіз останніх досліджень і публікацій. Аналіз основних підходів та концепцій зарубіжних дослідників дозволяе стверджувати, що західні дослідники у професійному самовизначенні бачать, як зараз заведено говорити, ресурс, потенціал і водночас стимул індивідуально-особистісного розвитку. Аналізуючи шляхи та механізми саморозвитку, вчені наголошують на індивідуальних відмінностях, необхідності їх всебічного вивчення, починаючи 3 раннього дитинства, та створення для цього необхідних умов. А. Маслоу, розглядаючи самоактуалізацію як вершину запропонованої ним піраміди потреб, у своїй концепції професійного самовизначення цю саму дефініцію розглядає як прагнення людини самовдосконалюватися, що, своєю чергою, бачиться можливим переважно у праці, зокрема «через захопленість роботою 
реалізувати себе у значній справі» [2]. Г. Олпорт у своїх дослідженнях наголошує на потребі у досягненні нових вершин, постійному розвитку та вдосконаленні, розглядаючи їх як основну умову людської активності [3].

Д. Холланд - автор профорієнтаційної методики - стверджує належність більшості оптантів одного з шести типів особистості, описаних ученим. Вибір професії, що відповідає типу особистості, багато в чому $є$ запорукою та успіхом професійних досягнень та кар'єрного зростання [4]. Е. Гінцберг підходить до проблеми професійного розвитку з позиції динаміки, розглядає його як тривалий процес, що передбачає прийняття професійних життєво важливих рішень, можливість компромісу зовнішніх та внутрішніх факторів.

Як основні внутрішні чинники виступають престиж професіі, особливості ринку праці та професій, головним внутрішнім фактором $є$ індивідуальні особливості особистості [5]. Д. Сьюпер, говорячи про професійне самовизначення, поділяє позицію, близьку до описаної вище, запроваджуючи поняття особистісної Я-концепції. Співвіднесення власного досвіду, особистісних особливостей iз соціальними вимогами та умовами вчений розглядає як найважливіший механізм професійного розвитку.

Виклад основного матеріалу. Професійне самовизначення вітчизняними вченими розглядається як процес прийняття особистістю рішення щодо вибору майбутньої трудової діяльності; процес та результат формування у підлітка готовності самостійно планувати та реалізовувати перспективи персонального освітньо-професійного маршруту. Е. Ф. Зеєр розглядає професійне самовизначення як «визначення свого місця у світі професій, знаходження особистісного сенсу у роботі» [7], А. К. Маркова професійне самовизначення пов'язує з визначенням людини себе щодо вироблених у суспільстві критеріїв професіоналізму [8], . А. Клімов професійне самовизначення співвідносить із «самоорієнтуванням» учня [9], Н. С. Пряжніков визначає сутність професійного самовизначення як «пошук та знаходження особистісного сенсу у обраній трудовій діяльності» [10], Л. М. Мітіна професійне самовизначення характеризує як прояв психічного розвитку людини в процесі професіоналізації [11].

Профорієнтація перестає бути окремим епізодичним заходом в школі. З'являється попит на інший тип профорієнтації - персоналізований, завдяки якому дитина зможе дізнатися про свої сильні сторони, інтереси, сформулювати життєві цілі і на цій основі вибрати те, чим реально хоче займатися, тобто збудувати свій персональний освітньо-професійний маршрут. Таким чином, виникає потреба в організації психолого-педагогічної підтримки учня на шляху вибудовування освітньо-професійного маршруту.

О. С. Газман розглядає педагогічну підтримку як особливу сферу діяльності педагога, спрямовану на стимулювання самостановлення дитини як індивідуальності [12]. Н. Н. Михайлова, С. М. Юсфін, розвиваючи підхід О. С. Газмана, визначають педагогічну підтримку як педагогічну діяльність, що підкріплює дитину у ситуації виявлення ним своєї слабкості та допомагає йому подолати їі за рахунок індивідуальних здібностей та можливостей [13]. 
Психолого-педагогічну підтримку можна визначити як систему психологопедагогічної діяльності, яка створює умови для вибудовування учнями індивідуальної освітньої траєкторії, що розглядається як шлях освоєння універсальних та професійних компетенцій, що формується учасником спільно 3 педагогом 3 використанням можливостей освітнього середовища [14] (профорієнтаційні програми та проекти, професійні змагання, професійні проби, стажування та т. д.). У цьому важлива актуалізація процесу самопізнання; створення ситуацій, у яких можна «спробувати себе» у різних видах діяльності, підтримка та розвиток корисних ініціатив; включення того, хто навчається в майбутню професійну діяльність, що передбачає конкретні практики; надання допомоги у визначенні напрямів свого саморозвитку.

Є. I. Ісаєв зазначає, що навчальна діяльність на середній та старшій щаблях школи набуває «форм проектної та власне дослідницької діяльності» [15]. Саме ці форми діяльності відповідають логіці розвитку людини на етапі підліткового віку та ранньої юності. Інтерес у підлітків викликає дослідницька робота, проектна діяльність, навчальне експериментування, спільна наукова робота 3 викладачем тощо. Для старшокласника значну допомогу у виборі професії може надати індивідуальний освітній маршрут, діяльність 3 формування професійного самовизначення (проба себе, участь в олімпіадах і конкурсах, добровольчої діяльності та ін.).

Пропонована нами програма психологічного супроводу школярів НУШ у період вибору профілю навчання передбачає участь соціального педагога, класного керівника, педагога-психолога, завдання яких - познайомити учнів 3 різними видами праці та професіями; вивчити схильності, особливості та професійні інтереси учнів, сформувати у школярів суспільно істотні мотиви вибору професії, особисті якості, допомагають їм самостійно прийняти рішення про професійне самовизначення. Для підлітків розроблено програму розвиваючих профорієнтаційних занять, мета якої - створити умови для підвищення готовності підлітків до самовизначення та свідомого вибору варіанта майбутнього навчання.

Завдання програми: 1) підвищити знання підлітків про світ професій, зміст різних видів професій, 2) створити умови для самопізнання, вміння адекватно оцінювати свої сильні та слабкі сторони, співвідносити їх до вимог професійної діяльності тощо.

У табл. 1 представимо фрагмент змісту програми.

\begin{tabular}{|r|c|c|c|}
\hline oㅡ П/I & Мета & Зміст & Устаткування \\
\hline $\mathbf{1}$ & Познайомити & Організаційна частина: & Папір, ручки, \\
& учасників 3 & привітання; & класний \\
& поняттям «здібності», & профорієнтаційна гра «Країна & дошка, крейда, \\
& іх роллю в житті та & професій». & дерево та \\
& професійній & Основна частина: & різнокольорові \\
& діяльності & «алітра ваших здібностей»; & яблука \\
& & бесіда про здібності. & (роздруковані) \\
& Рефлексія: & \\
& «Дерево почуттів» & \\
\hline
\end{tabular}




\begin{tabular}{|c|c|c|c|}
\hline 2 & $\begin{array}{c}\text { Знайомство з } \\
\text { навичками } \\
\text { самопрезентації; } \\
\text { формування } \\
\text { стійкого інтересу до } \\
\text { здобуття знань, } \\
\text { необхідних } \\
\text { для успішного } \\
\text { професійного } \\
\text { самовизначення }\end{array}$ & $\begin{array}{c}\text { Організаційна частина: } \\
\text { привітання, гра «Спляче місто». } \\
\text { Основна частина: } \\
\text { стратегії самопрезентації; } \\
\text { Рольова гра «Інтерв'ю». } \\
\text { Рефлексія: } \\
\text { «Якби... я став би...» }\end{array}$ & $\begin{array}{c}\text { Папір, ручки, } \\
\text { класна } \\
\text { дошка, крейда. } \\
\text { Таблиці } \\
\text { «Стратегії } \\
\text { самопрезентації», } \\
\text { «Ділові якості» }\end{array}$ \\
\hline 3 & $\begin{array}{c}\text { Допомогти учасникам } \\
\text { практично зрозуміти } \\
\text { особливості } \\
\text { усвідомленого вибору } \\
\text { професії. } \\
\text { Отримання } \\
\text { узагальнених } \\
\text { уявлень про } \\
\text { професійне майбутнє } \\
\text { кожного з } \\
\text { учасників на підставі } \\
\text { групових } \\
\text { рекомендацій, } \\
\text { зроблених } \\
\text { однокласниками }\end{array}$ & $\begin{array}{c}\text { Організаційна частина: } \\
\text { привітання; } \\
\text { гра «Абетка професій». } \\
\text { Основна частина: } \\
\text { вправи «Найкращий мотив», } \\
\text { «Радник». } \\
\text { Рефлексія: } \\
\text { питання, що вимагають } \\
\text { багатоваріантних відповідей }\end{array}$ & $\begin{array}{c}\text { Папір, ручки, } \\
\text { класна } \\
\text { дошка, крейда. } \\
\text { Бланк для } \\
\text { вправи «Радник» }\end{array}$ \\
\hline 4 & $\begin{array}{c}\text { Навчання стратегії } \\
\text { вибору. } \\
\text { Підвищити готовність } \\
\text { учасників } \\
\text { встановлювати } \\
\text { пріоритети під час } \\
\text { планування } \\
\text { свого життя та } \\
\text { кар'єрних } \\
\text { перспектив, а також їх } \\
\text { готовність } \\
\text { співвідносити свої } \\
\text { цілі та } \\
\text { кар'єрні можливості }\end{array}$ & $\begin{array}{c}\text { Організаційна частина: } \\
\text { привітання; } \\
\text { вправу «Відгадай професію». } \\
\text { Основна частина: } \\
\text { вправи "Стратегія професійного } \\
\text { вибору"; } \\
\text { "Твої перспективи"; } \\
\text { "5 кроків". } \\
\text { Рефлексія: } \\
\text { питання, що вимагають } \\
\text { багатоваріантних відповідей }\end{array}$ & $\begin{array}{c}\text { Папір, ручки, } \\
\text { класна } \\
\text { дошка, крейда, } \\
\text { олівці, } \\
\text { аркуші формату A4 }\end{array}$ \\
\hline
\end{tabular}

Фрагмент змісту програми психологічного супроводу школярів НУШ у період вибору профілю навчання

У нашому дослідженні взяли участь 95 учнів 8-х класів м. Києва. Для вивчення професійних нахилів у старших підлітків нами були використані такі психодіагностичні методики: «Вивчення здібностей учнів» (КОС) (В. В. Синявський, В. А. Федорошин); «Мотиви вибору професії» (Р. В. Овчарова); диференційно-діагностичний опитувальник (ДДО) (С. А. Клімов); тест Д. Голланда «Визначення типу особистості». 
Аналіз результатів дослідження дозволяє зробити такі висновки: більшість підлітків $(58,6 \%)$ віддають перевагу типу професії «людина - людина». Порядку половини учнів мають гарний рівень комунікативних $(54,73 \%)$ та організаторських $(52,32 \%)$ здібностей, що допоможе їм у професійній діяльності, більша частина опитуваних $(75,53 \%)$ не має усвідомленого вибору професії. Лише у 23\% підлітків мотиви вибору професії добре усвідомлювані та носять внутрішній індивідуально та соціально значимий характер. Переважаючими соціально-професійними типами стали соціальний (44\%), реалістичний $(36 \%)$ та заповзятливий $(28 \%)$.

Нами розроблено програму для старших підлітків 3 метою активізації професійного та особистісного самовизначення учнів. Завдання програми: розширити знання та уявлення учнів про світ професій, познайомити 3 правилами вибору професії, розвинути здібності до цілепокладання та цілереалізації, сформувати адекватне уявлення учнів про своє професійне потенціальне на основі самодіагностики та знання сучасного світу професій.

Як ще одна мета психологічного впливу вважаємо важливим розглянути особливості роботи з батьками підлітків та старшокласників. Батьківська некомпетентність, небажання та невміння чути, розуміти, приймати та поважати вибір та бажання власної дитини стають причинами конфліктів, неконструктивних рішень, переживань. Встановлення ряду батьків на те, що «батьки поганого не забажають», «вони життя прожили і знають краще, що й як...» часом небезпідставна. Тим часом, будучи впевненими у своїй правоті, батьки не беруть до уваги точку зору дитини, знецінюють ії, відмовляються «слухати» своїх дітей, починають давити, інколи шантажувати.

В силу вищесказаного вважаємо важливим ефективно та своєчасно організувати роботу з батьками у період вибору професійного шляху, прийняття рішення про майбутню професію. Досить добре зарекомендували себе такі форми роботи з батьками, як батьківські збори, індивідуальні та групові консультації, у тому числі спільно з учнями, анкетування, залучення батьків для виступів перед учнями, батьківські клуби, профорієнтаційні семінари спільно з учнями, у тому числі зі зміною ролей та подальшим їх обговоренням. У роботі 3 батьками вважаємо за важливе підвищити компетентність, створити умови для конструктивного діалогу, співпраці, можливості обговорення, прийняття рішення на основі взаємоповаги дітей та батьків.

Результати дослідження дозволяють сформулювати пропозиції щодо вдосконалення системи сучасної профорієнтації: 1) у цей час необхідно вибудовувати систему сучасної профорієнтації; для цього важливо визначити, до яких професій потрібно готувати учнів, виявити їх схильності та інтереси, проводити роботу з професійного самовизначення; 2) на кожному етапі дитинства важливо вивчати специфіку співвідношення стійких характеристик віку 3 тими особливостями, що набуваються в сьогоднішній конкретноісторичній ситуації, змін у постановці та досягненні професійних цілей для 
усвідомленого вибору професії; 3) актуалізувати ранню профорієнтацію учнів, починаючи з 6-го класу; 4) активно включати учнів та їхніх батьків у процес самовизначення; 5) профорієнтаційну роботу слід розглядати та вибудовувати як інтегральну складову навчально-виховної роботи освітньої організації; 6) розвивати активну профорієнтаційну діагностику, комплексну діагностику 3 використанням комп'ютерних систем, профорієнтаційну діагностику осіб 3 обмеженими можливостями здоров'я; 7) використовувати інформаційні, активізуючі, розвиваючі, діагностико-консультаційні методи; 8) обгрунтувати систему підготовки фахівців, готових та здатних вести профорієнтаційну роботу на якісно новому рівні; 9) систематично вивчати запити педагогів, психологів про нові технології ведення профорієнтаційної роботи; 10) організувати профорієнтаційну роботу 3 використанням можливостей освітнього середовища, соціальних партнерів, потреб регіону; при цьому важливо спрямовувати вихованців на соціокультурні зміни, у тому числі ставлення до себе, інших людей, до отримання нових знань; 11) готувати добровольців профорієнтаційної спрямованості, розвивати 12) інститут наставництва, спрямований формування культури професійного самовизначення; 13) поширювати ефективні практики профорієнтаційної роботи з учнями.

Таким чином, вивчення особливостей професійного самовизначення учнів iз подальшим використанням сучасних профорієнтаційних технологій сприятиме підвищенню ефективності професійного самовизначення дітей та молоді в Україні.

\section{Лimepamypa:}

1. Асмолов А. Г. О профессиях будущего. [Електронний ресурс] - Режим доступу:https://vogazeta.ru/articles/2018/9/5/quality_of_education/4551aleksandr_asmolov_o_pro fessiyah_buduschego.

2. Маслоу А. Мотивация и Личность. СПб.: Издательство Питер, 2006. 352 с.

3. Олпорт Г. Становление личности: избранные труды. М.: Смысл, 2002. 462 с.

4. Holland Y. L. (1968) Explorations of a theory of vocational choice // J. Appl. Psychol. London. V. 52. № 1. P. 13-27. (in English).

5. Occupational Choice. (1951) An Approach to a General Theory / E. Ginzberg, S. W. Ginsburg, S. Axelrad, J. L. Herma. New York: Columbia University Press; London: Oxford University Press. 271 p. (in English).

6. Super D. E., Bahn M. Y. (1971) Occupational psychology. - London: Tavistock. 2009 p. (in English).

7. Зеер Э. Ф. Психология профессий. М.: Академический Проект, Фонд «Мир», 2008. $336 \mathrm{c}$.

8. Маркова А. К. Психология профессионализма. М.: Международный гуманитарный фонд «Знание», 1996. $312 \mathrm{c}$.

9. Климов Е. А. Психология профессионального самоопределения. М.: Изд. центр «Академия», 2010. 304 с.

10. Вітомський Ю.Л., Бондаренко С.Ю., Гученко К.В. Логотерапія В.С. Франкла та тези екзистенційного аналізу крізь призму сенсу досвіду профорієнтаційної роботи за кордоном у контексті психологічної проблеми. The XI International Science Conference 
«Modern aspects of science and practice», November 30 - December 03, 2021, Melbourne, Australia. P. 495-504.

11. Бондаренко С.Ю., Вітомський Ю.Л. Поняття та сутність психологічної теорії вини в кримінальному праві. Актуальні проблеми кримінального права [Текст] : матеріали XII Всеукр. наук.-теорет. конф., присвяч. пам'яті проф. П. П. Михайленка (Київ, 18 листоп. 2021 р.) / [редкол.: В. В. Чернєй, С. Д. Гусарєв, С. С. Чернявський та ін.]. - Київ : Нац. акад. внутр. справ, 2021. С. 48-51.

12. Бондаренко С.Ю., Вітомський Ю.Л. Вина як прояв суспільних відносин у структурі психології девіантної поведінки через призму проблематики юридичної психології. «Перспективи та інновації науки (Серія «Педагогіка», Серія «Психологія», Серія «Медицина»)»: журнал. 2021. № 4(4) 2021. С. 341-353.

13. Бондаренко С.Ю., Вітомський Ю.Л. Психологічна теорія як онтологія походження держави, чи спроба вгамувати економічний детермінізм? The $\mathrm{X}$ International Science Conference «Science foundations of modern science and practice», November 23 - 26, 2021, Athens, Greece. P. 200-210.

14. Bondarenko S.Y., Vytomski Y.L. Conceptualism of education management: challenges of globalization. Розвиток самоефективної особистості: інтеграція зусиль суспільства, школи, родини: матеріали Міжнар. наук.-практ. конф. (м. Дніпро, 04 лист. 2021 р.). / ред. колегія: В.В. Сиченко, Т.О. Гальцева, Г.М. Стояцька, О.Г. Хватова. Дніпро: КЗВО «ДАНО» ДОР», 2021. C. $96-100$.

15. Пряжников Н. С. Профессиональное самоопределение: теория и практика. Москва.: Изд. центр «Академия», 2008. 320 с.

16. Митина Л. М., Кореляков Ю. А., Шавырина Г. В. Личность и профессия: психологическая поддержка и сопровождение / под ред. Л. М. Митиной. Москва.: Изд. центр «Академия», 2005. 336 с.

17. Газман О. С. Неклассическое воспитание: от авторитарной педагогики к педагогике свободы. - М.: МИРОС, 2002. С. 178.

18. Михайлова Н. Н., Юсфин С. М. Педагогика поддержки. - М.: МИРОС, 2001. 208 с.

19. Исаев Е. И. Психологическая антропология как составляющая педагогического образования // Антропологические перспективы психологического образования педагога: сборник научных трудов, посвященный 65- летнему юбилею доктора психологических наук, профессора Е. И. Исаева. - Тула: Изд-во Тул. гос. пед. ун-та им. Л. Н. Толстого, 2017. С. 5-17.

20. Сыманюк Э. Э., Печеркина А. А., Закревская О. В. Особенности профессионального самоопределения учащихся старшего подросткового возраста // Перспективы науки и образования. 2019. № 6 (42). С. 192-202.

21. Васильева Е.Н., Щербаков А. В. Гендерная специфика личностного компонента в структуре карьерного потенциала на начальном этапе обучения в вузе // Психологическая наука и образование. 2020. Т. 25. №1. С. 26-35.

22. Диагностический комплекс изучения потенциала профессионального развития личности обучающихся 8-9 классов / Е. В. Мялкина, Е. П. Седых, Д. И. Воронин, Т. Е. Федосеева, Н.Н.Куимова // Перспективы науки и образования. 2019. № 4 (40). С. 204-214.

23. Психолого-педагогические основы образования и развития конкурентоспособных кадров: монография / под ред. С. В. Пазухиной. - Гродно: ООО «ЮрСаПринт», 2017. С. 74-122.

24. Попов А. А. Сущность профильного обучения старшеклассников // Молодой ученый. 2015. № 17. С. 561-563.

\section{References:}

1. Asmolov, A. G. O professijah budushhego. [On the professions of the future]. Retrived from https://vogazeta.ru/articles/2018/9/5/quality_of_education/4551aleksandr_asmolov_ o_professiyah_buduschego [in Russian]. 
2. Maslou, A. (2006). Motivacija i Lichnost' [Motivation and Personality]. SPb.: Izdatel'stvo Piter [in Russian].

3. Olport, G. (2002). Stanovlenie lichnosti [Formation of personality]. M.: Smysl [in Russian].

4. Holland Y. L. (1968) Explorations of a theory of vocational choice // J. Appl. Psychol. London. V. 52. № 1. P. 13-27. (in English).

5. Occupational Choice. (1951) An Approach to a General Theory / E. Ginzberg, S. W. Ginsburg, S. Axelrad, J. L. Herma. New York: Columbia University Press; London: Oxford University Press. 271 p. (in English).

6. Super D. E., Bahn M. Y. (1971) Occupational psychology. - London: Tavistock. 209 p. (in English).

7. Zeer, Je. F. (2008). Psihologija professij [Psychology of professions.]. M.: Akademicheskij Proekt, Fond «Mir» [in Russian].

8. Markova, A. K. (1996). Psihologija professionalizma [Psychology of professionalism]. M.: Mezhdunarodnyj gumanitarnyj fond «Znanie» [in Russian].

9. Klimov, E. A. (2010). Psihologija professional'nogo samoopredelenija [Psychology of professional self-determination]. M.: Izd. centr «Akademija» [in Russian].

10. Vitoms'kij, Ju.L., Bondarenko, S.Ju., Guchenko, K.V. Logoterapija, V.C. (2021). Frankla ta tezi ekzistencijnogo analizu kriz' prizmu sensu dosvidu proforientacijnoï roboti za kordonom $u$ konteksti psihologichnoï problem [Frankl and theses of existential analysis through the prism of the meaning of the experience of career guidance abroad in the context of a psychological problem]. The XI International Science Conference «Modern aspects of science and practice»-The XI International Science Conference «Modern aspects of science and practice [in Ukrainian].

11. Bondarenko, S.Ju., Vitoms'kij, Ju.L. (2021). Ponjattja ta sutnist' psihologichnoï teoriï vini v kriminal'nomu pravi. Aktual'ni problemi kriminal'nogo prava [The concept and essence of the psychological theory of guilt in criminal law. Actual problems of criminal law]. The materiali XII Vseukr. nauk.-teoret. konf., prisvjach. pam'jati prof. P. P. Mihajlenka - Materials of XII All-Ukrainian. scientifictheoretical conf., dedicated. in memory of prof. PP Mykhaylenko in Ukrainian].

12. Bondarenko, S.Ju., Vitoms'kij, Ju.L. (2021). Vina jak projav suspil'nih vidnosin u strukturi psihologiï deviantnoï povedinki cherez prizmu problematiki juridichnoï psihologiï [Guilt as a manifestation of social relations in the structure of the psychology of deviant behavior through the prism of legal psychology]. Perspektivi ta innovaciï nauki (Serija "Pedagogika», Serija "Psihologija», Serija "Medicina») - Perspectives and innovations of science" ("Pedagogy" series, "Psychology" series, "Medicine" series). 4(4) 2021, 341-353 [in Ukrainian].

13. Bondarenko, S.Ju., Vitoms'kij, Ju.L. (2021). Psihologichna teorija jak ontologija pohodzhennja derzhavi, chi sproba vgamuvati ekonomichnij determinizm? [Psychological theory as an ontology of the origin of the state, or an attempt to appease economic determinism?]. The X International Science Conference «Science foundations of modern science and practice» - The X International Science Conference «Science foundations of modern science and practice» [in Ukrainian].

14. Bondarenko, S.Y., Vytomski, Y.L. (2021). Conceptualism of education management: challenges of globalization. Rozvitok samoefektivnoï osobistosti: integracija zusil' suspil'stva, shkoli, rodini [Conceptualism of education management: challenges of globalization. Development of self-effective personality: integration of efforts of society, school, family]. Th materiali Mizhnar. nauk.-prakt. konf. - The materials International. scientific-practical conf. [in Ukrainian].

15. Prjazhnikov, N. S. (2008). Professional'noe samoopredelenie: teorija i praktika [Professional self-determination: theory and practice]. Moskva.: Izd. centr «Akademija» [in Russian].

16. Mitina, L. M., Koreljakov, Ju. A., Shavyrina, G. V. (2005). Lichnost' i professija: psihologicheskaja podderzhka $i$ soprovozhdenie [Personality and profession: psychological support and support] Moskva.: Izd. centr «Akademija» [in Russian].

17. Gazman, O. S. (2002). Neklassicheskoe vospitanie: ot avtoritarnoj pedagogiki $k$ pedagogike svobody [Non-classical education: from authoritarian pedagogy to the pedagogy of freedom]. M.: MIROS [in Russian]. 
18. Mihajlova, N. N., Jusfin, S. M. (2001). Pedagogika podderzhki [Pedagogy of support]. M.: MIROS [in Russian].

19. Isaev, E. I. (2017). Psihologicheskaja antropologija kak sostavljajushhaja pedagogicheskogo obrazovanija [Psychological anthropology as a component of pedagogical education]. Antropologicheskie perspektivy psihologicheskogo obrazovanija pedagoga: sbornik nauchnyh trudov, posvjashhennyj 65- letnemu jubileju doktora psihologicheskih nauk, professora E. I. Isaeva - Anthropological prospects of psychological education of teachers: a collection of scientific papers dedicated to the 65th anniversary of Doctor of Psychological Sciences, Professor EI Isaev, 5-17 [in Russian].

20. Symanjuk, Je. Je., Pecherkina, A. A., Zakrevskaja, O. V. (2019). Osobennosti professional'nogo samoopredelenija uchashhihsja starshego podrostkovogo vozrasta [Features of professional self-determination of older adolescents]. Perspektivy nauki i obrazovanija - Prospects of science and education, 6 (42), 192-202 [in Russian].

21. Vasil'eva, E.N., Shherbakov, A. V. (2020). Gendernaja specifika lichnostnogo komponenta $\mathrm{v}$ strukture kar'ernogo potenciala na nachal'nom jetape obuchenija $\mathrm{v}$ vuze [Gender specifics of the personal component in the structure of career potential at the initial stage of education in higher education]. Psihologicheskaja nauka i obrazovanie - Psychological science and education, 25, 1, 26-35 [in Russian].

22. Mjalkina, E. V., Sedyh, E. P., Voronin, D. I., Fedoseeva, T. E. , Kuimova N. N. (2019). Diagnosticheskij kompleks izuchenija potenciala professional'nogo razvitija lichnosti obuchajushhihsja 8-9 klassov [Diagnostic complex of studying the potential of professional development of the personality of students of 8-9 grades]. Perspektivy nauki i obrazovanija Perspectives of Science and Education, 4 (40), 204-214 [in Russian].

23. Pazuhina, S. V. (2017). Psihologo-pedagogicheskie osnovy obrazovanija i razvitija konkurentosposobnyh kadrov: monografija [Psychological and pedagogical foundations of education and development of competitive personnel]. Grodno: OOO «JurSaPrint» [in Russian].

24. Popov, A. A. (2015). Sushhnost' profil'nogo obuchenija starsheklassnikov [The essence of specialized training of high school students]. Molodoj uchenyj - Young scientist, 17, 561-563 [in Russian]. 